\title{
Literacy Gender in Elementary School Education
}

\author{
Darni $^{1}{ }^{*}$ Yuni Lestari ${ }^{2}$, Putri Aisyiyah Rachma Dewi ${ }^{3}$
}

\author{
${ }^{1}$ Deparment of Regional Language and Literature, Universitas Negeri Surabaya \\ ${ }^{2}$ Public Administration of Vocational Program, Universitas Negeri Surabaya \\ ${ }^{3}$ Department of Communication Science, Universitas Negeri Surabaya \\ *Corresponding author.Email: darni@unesa.ac.id
}

\begin{abstract}
There is a lot of research on gender understanding in schools which shows that there are still teachers who show discriminatory values, attitudes, and behaviors towards their students. The teacher's lack of awareness and understanding of the correct gender concept is one of the causes of this bias condition. This is exacerbated when the teachers do not realize that the behaviors that are shown are gender-biased. The teachers assume that the patterns of attitudes and behavior that are usually carried out so far are part of the community's culture which is considered correct. The paper is written using the literature review method and a comparative study approach. This paper describes the literacy of gender and gender-based education in Indonesia-Malaysia. In Indonesia and Malaysia, the dominance of women in public areas, especially in the field of education, does not seem to have had a significant impact on women's dominance in decision-making and leadership. Both countries are still dominated by a patriarchal culture that considers that the role of leaders and decision-makers is an area of the men's role.
\end{abstract}

Keywords: gender mainstreaming, gender literacy, educators' gender perspective, comparative study IndonesiaMalaysia

\section{INTRODUCTION}

Various studies have shown that schools have a significant role in building individual gender understanding and gender-based scientific segregation. Research conducted by Vasalampi et al shows that the process of building students' self-concept in the classroom affects their abilities in the fields of literacy and mathematics. Female students, at various levels of primary school, show better abilities in literacy than their male counterparts. However, they have less ability in mathematics. The children believed that it was indeed more difficult for female students to understand numbers. The opposite condition occurs in male students, class atmosphere, and teacher motivation, affecting their self-concept so that they show better abilities in mathematics than literacy [1].

These findings are in line with research conducted by Puchner et al. shows that women are still a minority in the STEM (science, technology, engineering, mathematics) professions. This condition is due to policies and discriminatory treatment by schools, campuses/institutions, and workplaces. Low self-concept towards STEM in women is formed since they were in elementary school. What they got from teachers, textbooks, and other teaching materials is that the STEM profession is not a profession suitable for women [2].

Teachers in schools are against this finding. They feel they have a positive attitude towards students, both male and female. They have also given the same task to all students regardless of gender. However, the results of the observations said otherwise, that the teachers showed values, attitudes, and behaviors that were discriminatory towards male students and female students. The denials that were given at the beginning were because they did not have good awareness and understanding of the concept of gender bias [3].

A good understanding of gender among students will enable them to maximize their potential, and give them more choices for activities and professions when in society. For this reason, teachers with good gender literacy are an inevitable need in the learning process. Experimental research conducted by Friesem [4] in a classroom in an elementary school shows that there are significant changes in students when the teacher who teaches is someone who has excellent gender literacy. The students in the pre-experiment showed low self-concept and low critical reasoning of the gender bias scores around them. However, post-experiment, these children were able to change their self-concept to be more 
positive in both male and female students. Both have critical reasoning power in consuming gender-biased media messages and are even able to show social awareness movement initiatives to their peers in terms of gender literacy.

Elementary school is an important level in cultivating gender understanding and awareness. The teacher is an important factor in this task. Teachers who understand and are gender-responsive will carry out learning management with full awareness of Gender Mainstreaming (PUG) [5][6].

\section{METHOD}

A literature review is a method of critically analyzing, evaluating, and synthesizing research findings, theories and practices carried out by researchers and scholars. In this method, the author presents a comprehensive, critical, and accurate understanding of current knowledge [7]. In line with this opinion, Romi Satria Wahono, an expert in research methodology, explained that literature review does not only mean reading literature but rather towards an in-depth and critical evaluation of previous research on a research topic. The results of the evaluation are then summarized, analyzed, synthesized the content, and presented it in the form of a survey paper [8]. One approach used in this method is a comparative study. Likewise in writing this paper where the author uses a comparative study to describe gender literacy in education in Indonesia and Malaysia. By finding the differences between the two, the authors can follow up and provide advice on further research.

\section{RESULT AND DISCUSSION}

\subsection{Gender Literacy}

The gender theme is not a theme that only discusses everything that deals with women. So far, there is still an inaccurate understanding of the concept of gender. It is inevitable that gender is interpreted as a role attached to a certain gender and is increasingly interpreted as destiny/nature. This condition illustrates that currently the socialization of understanding gender properly is still very much needed and continues to be echoed in the community.

Talking about gender, it discusses the roles played by men and women who are usually very strongly influenced by the culture of the local community. Gender is defined as a group of attributes and behaviors that are shaped culturally and are in men or women [9]. The formation of gender is influenced by many factors, which are then socialized, strengthened, even constructed through social or cultural, perpetuated by religious interpretations and myths, and as if it has become natural, unchangeable beliefs [10]. Mufidah provides a simple meaning that gender is a social sex/gender that can change according to the times [11].
If many people are still sensitive to gender themes, actually gender differences do not always create gender inequalities. This problem will not occur if everyone has a correct understanding of gender. Gender inequality is a system and structure where men and women become victims of the system. Nugroho [12] argues that gender inequalities can be understood in several manifestations, including: (1) marginalization (impoverishment as a result of certain policies), (2) subordination (domestication of position), (3) stereotypes (negative labeling), (4) violence (physical or nonphysical attacks), and (5) double burden (underestimating domestic workloads).

The potential for violence can be carried out by those who have superior power against those who do not have power (inferior), thus causing suffering for those parties [10]. Hobbes, A philosopher with the work "Leviathan", explains that power relations are exploitative and repressive where the rulers tend to use violence to maintain their power [13][14].

Based on the categorization of places where violence occurs, gender-based violence can occur both within the family environment (domestic violence) and outside the family environment (non-domestic violence). Violence against women outside the family environment can occur in; (1) community environments and public places, (2) workplaces, (3) mass media, and (4) state violence [15].

\subsection{Gender-Based Education in Indonesia and Malaysia}

One thing that cannot be denied that is the culture of society also affects the level of education of the community. In a patriarchal society, women's education for some people is still secondary. The existence of culture and institutions requires women to be weak and succumb to family relationships, by seeing women as weak, men's instrumental roles are considered more objective than women's feelings[16][17]. This affects the form and pattern of education in schools.

Emancipation and gender equality in various development sectors have been echoed in all countries. Gender issues, especially in education, often draw criticism from feminist and gender experts. Many research experts, among others, explain that gender has a biological impact on differences in certain academic abilities between male and female students, textbook material has an important role in shaping the gender roles of students, even the selection of majors for students is often based on appropriateness of certain gender roles [17]. Based on data taken from the Central Statistics Agency of the Republic of Indonesia in 2009-2020, it shows that the School Participation Rate (Angka Partisipasi Sekolah/APS) for the population aged 718 years does not show that women's participation in education is increasing from year to year and from basic to upper levels. In detail, it can be seen that the APS in Elementary Schools (7-12 years old) in 2020 is $99,10 \%$ for boys and 99,32\% for girls. The APS in Middle Schools (1315 years old) in 2020 is $94,63 \%$ for boys and $96,47 \%$ for 
girls. The APS for Senior High Schools (16-18 years old) in 2020 is $70,78 \%$ for boys and $72,13 \%$ for girls [18].

Table 1. School Enrollment Rate in Indonesia in 2020

\begin{tabular}{|c|c|c|}
\hline $\begin{array}{l}\text { Level } \\
\text { Education }\end{array}$ & irls $(\%)$ & oys $(\%)$ \\
\hline $\begin{array}{lr} & \text { Elementar } \\
\text { y } & \text { School } \quad(7-12 \\
\text { years old })\end{array}$ & 9,32 & 9,10 \\
\hline \begin{tabular}{l}
\multicolumn{2}{c}{ Middle } \\
Schools $(13-15$ \\
years old $)$
\end{tabular} & 6,47 & 4,63 \\
\hline $\begin{array}{lll} & \text { Senior } & \text { High } \\
\text { Schools } & & \\
& (16-18 & \text { years } \\
\text { old }) & & \end{array}$ & 2,13 & 0,78 \\
\hline
\end{tabular}

Resource: Central Statistics Agency of Republic Indonesia

Based on the data, it is shown that the APS rate of girls/teenagers is higher than boys/teenagers. In addition, the higher the education level of children/teenagers, the lower the school enrollment rate.

Switching from the APS data, data from the Ministry of Education and Culture (Ministry of Education and Culture of the Republic of Indonesia) on the Number of Principals and Teachers by Gender at the Elementary School Level in Indonesia in 2019/2020 showed 556,969 teachers with details of $163,679(19,4 \%)$ male teachers and 393,290 $(70,6 \%)$ female teachers. [19]. The existence of such data will certainly bring positive news for gender and women observers in the field of education, especially in Indonesia.

But in reality, these data do not necessarily bring changes to the patriarchal culture that certain people believe in. It is an undeniable fact that in Indonesia there are still social groups/cultures that position boys as a priority in gaining access to education compared to girls. Family considerations based on patriarchal culture position women as not in need of higher education. Society often positions women in a condition of subordination, women's fate is ultimate to serve their husbands as wives and mothers for children who will be born in the future [17]. In this case, it can be concluded that culture and economic conditions have a close relationship. As the backbone of the family, it is appropriate that men get priority in education. This is inseparable from the community's assumption that family poverty is strongly influenced by the choice of parents in providing access to education for their children.

In the old understanding, the curriculum is more often defined as a collection of subjects. In its development, the curriculum is defined as a basic guideline for education providers to carry out the learning process. In a scientific paper entitled "Basic Education Curriculum in Gender Perspective", it is explained that gender perspective curriculum reform is one of the right answers to make improvements to the education system and culture in Indonesia [20][21]. In research conducted by previous authors who believe that the quality of a country's human resources is strongly influenced by the quality of that country's education [21]. The achievement of educational goals can be realized through good curriculum design.

The existence of culture not only influences family parenting but also affects the teaching pattern of the teachers in school. A teacher who is accustomed to living in a patriarchal environment, it is likely that the pattern of students used is patriarchal. A study in Tanzania revealed that a patriarchal culture caused female teachers to receive a double burden. When a teacher has the status of a mother at the same time, the work of caring for children and the household chores becomes the responsibility of women. Tanzanian men perceive domestic duties as women's duties and it becomes impossible when women workers ask men for help in completing domestic tasks [22]. Most of the conditions in Tanzania also occurred in Indonesia and Malaysia.

Data in Malaysia shows that women dominate the public sector, especially in the education sector. As many as $72.3 \%$ of teachers in Malaysia are female, while the remaining 27.7\% are male. From a data 0n 2020 about the Distribution of Teachers at Pre-school, Primary and Secondary Schools in Malaysia, it was found that the number of teachers was 412,720 with details of 285,299 female teachers and 127,421 male teachers. In addition, statistical data shows that the education of Malaysian women from diploma, undergraduate, to master level reaches a percentage above $50 \%$ and at the $\mathrm{Ph} . \mathrm{D}$. level is $38.1 \%$. This shows that women's awareness of education has progressed from time to time [23]. In the perception of teachers in Malaysia that female students have better achievement efforts than male students [24][25]. This condition is not strong enough to change people's perceptions amidst the thick atriarchal culture in Malaysia, some people still think that men still play an important role in leadership and decision making.

\subsection{Gender-Based Leadership in Indonesia and Malaysia}

Leadership is used as a measure or indicator of a person's success in leading a particular organization or group of communities. Organizational success is never separated from the skills or strengths of a leader. Fitriani argues that the skills or strengths of the leader are the capital for the leader to be able to influence others to achieve certain goals through certain activities, such as caring, supporting, and motivating subordinates [26][26]. A good leader is expected to be able to bind, harmonize, and encourage subordinates to compete in fairness and a good manner.

In the midst of the appropriateness and feasibility of leadership, both men and women, the competence of the leader become the most fearful measuring indicator that can be used to assess the appropriateness of a person to occupy a chair of leadership. According to Robbins [26], a leader 
should have 3 main characteristics, namely: (a) Social Perception, a leader's ability to see and understand the attitudes/behavior and needs of subordinates; (b) Skill of Abstract Thinking, the leader has high intelligence and the ability to think simply; (c) Emotional Balance, a leader has emotional maturity (deep awareness of needs, desires, aspirations, and feelings), thus creating a harmonious personality. When women have the competencies (skills) and characteristics of a leader above, it is inappropriate when there is still a perception that women are said to be unfit for leadership positions.

These roles can be exchanged between men and women. Islamic teaching explains that men and women have the same position and what distinguishes between the two is the level of devotion to Allah SWT. Surah At-Taubah verse 71 can be translated as follows: "The believing men and believing women are allies of one another. They enjoin what is right and forbid what is wrong and establish prayer and give zakah and obey Allah and His Messenger. Those - Allah will have mercy upon them. Indeed, Allah is Exalted in Might and Wise."This verse very clearly explains the equal position between men and women and both are created to work together and complement each other [26]. This statement is sufficient to reason that both women and men have the same opportunity to occupy leadership positions.

A study in Malaysia on women's leadership obtained data that women's and men's leadership were equally effective [27]. The success of female leaders cannot be separated from the ability to collaborate and affection. Another finding also states that female leadership gets positive perceptions from female employees compared to male employees. This shows that the ability to empathize with each other has an impact on the progress of women themselves. However, this research does not deny that gender bias still exists in society. Therefore, more actions should be taken to educate the public and promote awareness of gender equality.

\section{CONCLUSION}

Understanding the gender of a country's society certainly has an impact on the development of a gender perspective in a country. A country's Gender Development Index (GDI) will increase when gender perspective human resources increase through the formation of gender perspective education. The existence of teachers who can understand the concept of gender well is an important capital in realizing gender perspective education. The domination of women in the public area or the field of education, both in Indonesia and Malaysia does not seem to have had a significant impact on increasing public understanding of gender equality. This is in line with how society still positions men as dominant actors in decisionmaking and leadership. The strength of the patriarchal culture in both countries further perpetuates the notion that leadership is the domain of men, thus making it more difficult for women to achieve leadership positions.

\section{ACKNOWLEDGMENTS}

A big thank to the Rector of Universitas Negeri Surabaya. Thanks for giving support and international conference funding. By those, this international proceeding paper can be carried out.

\section{REFERENCES}

[1] K. Vasalampi, E. Pakarinen, M. Torppa, J. Viljaranta, M. K. Lerkkanen, and A. M. Poikkeus, "Classroom effect on primary school students' self-concept in literacy and mathematics," Eur. J. Psychol. Educ., vol. 35, no. 3, pp. 625-646, 2020.

[2] L. Puchner, L. Markowitz, and M. Hedley, "Critical Media Literacy and Gender: Teaching Middle School Children about Gender Stereotypes and Occupations," J. Media Lit. Educ., vol. 7, no. 2, pp. 23-34, 2015.

[3] M. B. Khan, S. Mughal, S. U. Rehman, and N. Saif, "Gender Stereotypes and Teachers Perceptions ( The Case of," vol. 2, no. 7, pp. 17-29, 2012.

[4] E. Friesem, "Developing Media and Gender Literacy in the High School Classroom.," J. Lit. Technol., vol. 18, no. 2, pp. 154-191, 2017.

[5] Y. Ermawati, Darni, Surana, Murdiyanto, and S. Adipitoyo, "Building the Character of Elementary School Students through Javanese Language Learning," vol. 390, no. Icracos 2019, pp. 157- 161, 2020.

[6] P. W. S. J. Watson et al., "Teacher gender, and expectation of reading achievement in New Zealand elementary school students: essentially a barrier?," Gend. Educ., vol. 31, no. 8, pp. 1000-1019, 2019.

[7] S. E. Efron and R. Ravid, Writing The Literature Review: A Practical Guide. London, New York: The Guilford Press, 2019.

[8] R. S. Wahono, "LITERATURE REVIEW: PENGANTAR DAN METODE,"

RomiSatriaWahono.Net, 2016. [Online]. Available: https://romisatriawahono.net/2016/05/07/literaturereview- pengantar-dan-metode/. [Accessed: 25-Jul2021].

[9] S. Fatimah, S. Sili, and C. Asanti, "The Masculinity and Femininity Traits of Female Character in Roth ' S," vol. 3, no. 4, pp. 404-412, 2019.

[10] Darni, Kekerasan terhadap Perempuan dalam Fiksi Jawa Modern (Sebuah Kritik Sastra). Surabaya: Unesa University Press, 2021.

[11] Mufidah Ch., Pengarusutamaan Gender Pada Basis Keagamaan (Pendekatan Islam, Strukturisasi, dan Konstruksi Sosial), 1st ed. Malang: UIN-Malang Press, 2009.

[12] R. Nugroho, Gender dan Strategi Pengarusutamaannya di Indonesia. Yogyakarta: Pustaka Pelajar, 2011. 
[13] Ridwan, Kekerasan Berbasis Gender (Rekonstruksi Teologis, Yuridis, dan Sosiologis. Yogyakarta: Pusat Studi Gender STAIN Purwokerto dan Fajar Pustaka, 2006.

[14] P. A. Van der Weij, Filsuf-Filsuf Besartentang Manusia. Jakarta: Gramedia, 2017.

[15] T. A. Tomagola, "Restu Sosial-Budaya atas Kekerasan Terhadap Perempuan," in Negara dan Kekerasan Terhadap Perempuan, N. I. Subono, Ed. Jakarta: Yayasan Perempuan Indonesia, 2000, pp. 99-113.

[16] L. Wati and Rasyidah, "PEREMPUAN DAN PENDIDIKAN DALAM PERSPEKTIF GENDER," Ilm. Mhs. FISIP UNSYIAH, vol. 3, no. 4, pp. 1-12, 2019.

[17] T. Ni'am, "Pendidikan Perspektif Gender Di Indonesia (Menimbang dan Menakar Peran Gender dalam Pendidikan)," J. Kesetaraan dan Keadilan Gend., vol. 10, no. 1, pp. 1-15, 2017.

[18] Badan Pusat Statistik RI, “Angka Partisipasi Sekolah (APS) Penduduk Usia 7-18 Tahun Menurut Tipe Daerah, Jenis Kelamin dan Kelompok Umur, 20092020," Jakarta, 2020.

[19] Kemendikbud RI, "JUMLAH KEPALA SEKOLAH DAN GURU MENURUT JENIS KELAMIN DAN STATUS SEKOLAH TIAP PROPINSI PADA TINGKAT SEKOLAH DASAR TAHUN 2019/2020," Jakarta, 2020.

[20] M. Mustaqim, "Kurikulum Pendidikan Dasar Dalam
Perspektif Gender," Edukasia J. Penelit. Pendidik. Islam, vol. 9, no. 1, pp. 113-128, 2014.

[21] Y. Lestari, "Pendidikan Perspektif Gender (Studi Tentang Orientasi Pembentukan Kurikulum Sekolah Perspektif Gender di Pusat Studi Wanita Universitas Negeri Surabaya)," Malang, 2008.

[22] S. Tao, "Female teachers in Tanzania: an analysis of gender, poverty and constrained capabilities," Gend. Educ., vol. 31, no. 7, pp. 903-919, 2019.

[23] L. Ismail, "Gender gap in higher education: Perspective on factors influencing enrolment in Malaysian universities: A University of Malaya sample," Online J. Qual. High. Educ., vol. 2, no. 4, pp. 35-45, 2015.

[24] S. Nachiappan, V. P. K. Veeran, and H. K. Andi, "Gender issues in malaysian education: Factors influencing male and female students' academic achievement through cognitive processes in public examinations," Int. J. Bus. Soc. Res., vol. 2, no. 2, pp. 133-150, 2013.

[25] Z. M. Jelas et al., "Gender Disparity in School Participation and Achievement: The Case in Malaysia," Procedia - Soc. Behav. Sci., vol. 140, pp. 62-68, 2014.

[26] A. Fitriani, "Gaya Kepemimpinan Perempuan," $J$. TAPIs, vol. 11, no. 2, pp. 1-24, 2015.

[27] H. Hilal, "Perceptions towards Female Leadership in Malaysia," J. Mod. Educ. Rev., vol. 5, no. 5, pp. 517525,2015 